\title{
Implementation of Learning Online in Pesantren in The Facing of Pandemic Covid 19
}

\author{
Muhamad Murtadlo ${ }^{1}$, Sumarni ${ }^{2}$, Elma Haryani ${ }^{3}$, Iyoh Mastiyah ${ }^{4}$, Lisa'diyah Ma'rifataini ${ }^{5}$, \\ Abdul Kadir Ahmad ${ }^{6}$, Elis Lisyawati ${ }^{7}$ \\ \{murtadlo@kemenag.go.id ${ }^{1}$; marni_ch@yahoo.com.au²; elmaharyani@kemenag.go.id ${ }^{3}$; \\ mastiyah9@gmail.com ${ }^{4}$; lisa.litbang@gmail.com ${ }^{5}$, abduladir76@gmail.com ${ }^{6}$; liesgeulis79@gmail.com ${ }^{7}$ \\ I \\ Puslitbang Pendidikan Agama dan Keagamaan ${ }^{1,2,4,5,6}$ \\ Puslitbang Bimas Agama dan Layanan Keagamaan ${ }^{3}$, Universitas Nahdlatul Ulama Indonesia ${ }^{7}$
}

\begin{abstract}
This writing wants to describe the practice of learning in a religious education institution called pesantren. When other educational institutions are forced to carry out online learning in the pandemic Covid 19, how canspesantren as religious education institutions respond to the demand of practicing online learning. The research question was formulated how online learning practices are applied in pesantren. This research is a type of case research, namely the case of the pesantren An Nahdah in Bojongsari, Depok, West Java. The results showed that online learning in pesantren was less than optimal. This is due to the assumption that pesantren residents still have the notion that gaget provides more education than benefits for the development of education in the pesantren. This is the main source of the problem of pesantren's failure to face learning during a pandemic or the development of post-pandemic online learning later. This situation implies that many santri do not interpret the presence of gaget creatively, they use gaget more as a means of entertainment. This paper recommends the need for more constructive efforts in building a positive view of information technology.
\end{abstract}

Keywords: online learning, pesantren, santri response, information technology

\section{A. Introduction}

The Covid 19 pandemic has devastated various life systems experienced by all countries, such as economy, politics, including in the world of education. All we were forced to lay down for a while to avoid the impact of this pandemic. But on the other hand, certain functions such as formal education are required to run. Online learning is the only answer to learning in this pandemic. It's just that most students do not enjoy or fail to understand this online learning. The data shows that online learning for secondary education level students is only enjoyed by $9.4 \%$, the remaining $90.6 \%$ prefer face-to-face learning (Padli and Rusdi, 2020). This is different when compared to the world of students who tend not to be too stuttering with technology. The research of Khasanah et al shows that $82 \%$ of students support the implementation of education through webinars, while the other $18 \%$ do not support the implementation of webinar tutorials (Khasanah et al, 2020).

Studies on online learning during the pandemic can be grouped, among others: first, groups that try to map students' responses to online learning (Khasanah, Pramudibyanto and 
Widuroyekti, 2020; Padli and Rusdi, 2020); second, groups that try to map the problems faced in online learning (Oktawirawan 2020; Setyorini 2020); third, groups that are trying to be optimistic about implementing online learning in educational institutions (Abidin, Rumansyah and Arizona, 2020; and Pujiasih, 2020)

Online learning, either because of the demands of the times or because of compulsion due to the Covid 19 pandemic, is a learning model that educational institutions have started to become familiar with. The pluses and minuses of online learning need to be considered to improve the ability and quality of online learning. Much writing has been done on the implications of this pandemic for education. This research wants to try to study online learning in the pesantren environment. Generally, pesantren prohibits students from carrying communication media such as cellphones, because this is considered to disturb the concentration of the students. This is different from non-pesantren school students, because they are currently holding cellphones outside of school hours at junior and senior high school. Why pesantren? This is because: first, Islamic boarding schools apart from being educational institutions, are also considered as representatives of religious institutions that are suspected of having special tricks in dealing with the pandemic. The religious approach is one of the pillars that is expected to provide an alternative solution to the confusion caused by this pandemic. Second, pesantren in general have so far avoided the use of online media such as cellphones during the time the students lived in the pesantren environment.

The research question was formulated: How is the development of online learning developed in pesantren? This question is detailed with sub-questions: how is the practice of learning from during the Covid 19 pandemic. This question looks at a picture of the practice that has been carried out by the pesantren in maintaining continuity of learning during the Covid 19 pandemic. 19. The second question is to measure how information technology is adapted by pesantren. This study aims to see the response of pesantren education institutions in adapting online learning in the pesantren environment during the Covid 19 pandemic, and to find out the readiness of the pesantren to develop online-based learning models. This is to answer the challenge that in order to avoid being left behind in the field of information, the pesantren world needs to be familiar with online media in absorbing and developing information.

\section{B. Literature Review}

Several studies related to online learning during the Covid 19 pandemic in this study began with reading the initial map of the study of this problem. In this context, the authors mention there are at least three trends of reviewers in viewing online learning during this pandemic, namely studies that read students' responses through small surveys; second, a study of the problems faced in online learning during a pandemic; and third, studies that try to build optimism about the need to develop online learning either because of the pandemic or further interest in the development of future learning.

Regarding the response of students at various levels of educational institutions. Among students, learning webinars is quite enjoyable for most students. Khasanah et al's study on Open University (UT) students showed that $82 \%$ of students supported the implementation of education through webinars, while $18 \%$ did not support the implementation of webinar tutorials (tuweb) because they did not have a device (laptop / pc). Generally, students rely on cellphone webinar tutorials only. Students who are not confident in learning this model want to be given assignments (independent study) during the pandemic period (Khasanah et al, 2020). This is different from online learning in secondary education students. At the Aliyah level student level based on research on Al Amin Tabab Bali Madrasah (MA) students shows that student 
responses to learning in the network during the corona virus pandemic, namely online learning are less enjoyable because the material described is less understood, quota limitations, application errors and lack of guidance by the teacher (Arifin 2020).

Regarding the problems faced in implementing online learning during the Covid 19 pandemic, the school closure policy as an effort to cut the chain of the Covid 19 pandemic according to some people is not supported by adequate data. Meanwhile, the policy of closing has implications for high absenteeism of school staff and puts the school system under pressure. Many things were sacrificed due to the closure of this educational process. Vider et al. Suggest that schools continue to operate for children and education managers with adequate health may be a better strategy than the haphazard process of closing schools (Viner et al. 2020). Technical difficulties in gathering, because there is an appeal from the Indonesian government to take social distanching has caused the educational process to be arbitrary. One way out is the implementation of learning that is carried out with online facilities. It's just that this online learning technique raises three problems at least in the school tradition: the need for online learning costs; decreasing role of existing evaluation methods; potential loss of academic integrity (Discenza, Howard and Schenk, 2002).

Regarding building a sense of optimism in using online learning, there are differences in the ability of students to understand English text between before and after using a web blog. In this case, online learning assisted by the web blog has a positive effect on improving students' English reading skills (Khusniyah and Hakim, 2019).

From the concept map above, this study tries to read three things, namely responses, problems and efforts to build optimism for the use of online learning in the scope of Islamic boarding schools. The description of these three things is important in order to read the readiness of pesantren to take advantage of technological advances in the development of online learning, especially when currently all educational institutions are trying to formulate online learning in the midst of a pandemic.

\section{Research Methods}

This study uses a qualitative research approach by exploring the trend of many Islamic boarding schools in providing education to respond to the atmosphere of the Covid 19 Pandemic by sharpening it in a case study of the pesantren. The case chosen was the development of online learning at the An Nahdah Islamic boarding school, Pondok Petir, Bojongsari, Depok. The reasons for choosing this case are: first, this pesantren represents the nahdliyin community which so far emphasizes our reading ability in yellow (non-sacred books); second, this pesantren also develops formal education, namely madrasah tsanawiyah (SMP level education) and madrasah aliyah (high school level education).

Data collection was carried out in June 2020 by reading research results, observations, in-depth interviews and online surveys. Reading the research results is used to read the trend of Islamic boarding schools in responding to online learning during the Covid 19 pandemic. Observations were made to see firsthand the practice of developing online learning implemented in this pesantren. Interviews were conducted face-to-face with informants and mostly conducted by means of online communication (considering that it was still during the Covid 19 pandemic). Online surveys are used to see variations in the views of both teachers and students on the implementation of online learning. To strengthen the data, online surveys were conducted not only for teachers and students at the target pesantren, but also online surveys which were distributed to the pesantren community in general.

The collected data are then grouped based on the map of the data needed. The map required includes a general description of the tendency of pesantren to respond to online 
learning, online learning system development, classroom learning, learning the yellow book (outside the classroom), teacher and student responses and responses. Each group of data is then used to create a narrative after previously triangulating with other data groups to describe a complete description of the research objectives.

Data analysis was carried out in an exploratory way, namely the deepening of the general tendency of pesantren attitudes in facing the Covid 19 Pandemic with one case of the pesantren as the research target. The evidence found in the case of the target pesantren provides a qualitative insight into the pesantren's attitudes in responding to online learning. This was chosen considering that online learning at the pesantren was still considered early or even some were still not using cellphones at the pesantren.

\section{Findings and Discussion}

\section{The Covid 19 Pandemic and Continuity of Learning in Islamic Boarding Schools}

During the Covid 19 Pandemic, many Islamic boarding schools in Indonesia followed the government's option in dealing with the dangers of this pandemic by carrying out Social Distanching, taking social distancing by returning students to their parents. Starting from the first week of March 2020 until an undetermined time, the students are permitted or indeed recommended to return to their respective homes. This repatriation is valid indefinitely and awaits the development of the pandemic itself. As of this writing in June, the policy of housing students is still running.

The Center for Religious and Religious Education Research and Development in June 2020 conducted a rapid survey regarding the readiness of pesantren to face Covid 19 and the pesantren's response to the government's call to familiarize with this pandemic by starting to turn on life activities, or often called new normal. This rapid survey involved 1262 Islamic boarding schools in 29 provinces in Indonesia. In terms of the profile of the pesantren that were netted, $15 \%$ of the pesantren were categorized as only carrying out religious recitation (the salafiyah category of pesantren), and the remaining $85 \%$ of the pesantren that had services other than religious recitation also provided other education (category of khalafiyah pesantren). The results of this quick survey get the following picture

Starting from the policy of returning the students to their parents. In responding to this, the pesantren's response is divided into three: repatriating all the students, repatriating some of the students, and keeping the students at the pesantren. Pesantren which have a policy of repatriating all students as much as $71.1 \%$, pesantren which repatriate only part of the students $19.7 \%$, and pesantren that do not repatriate as many as $9.2 \%$. The consideration of the pesantren to repatriate students mostly because of the government's appeal to carry out social distanching of the danger of covid 19 transmission as much as $66.9 \%$; Islamic boarding schools that do not want to bear the risk of their institutions becoming clusters of outbreaks of $22.5 \%$; The wishes of the parents of students $3,8 \%$; the appeal of religious oramas as much as $6.8 \%$. Meanwhile, the pesantren that survived did not send their students home based on the consideration that the pesantren environment was safer than when the students were at home and the activities of the Koran at the pesantren were better than other activities.

Furthermore, during the repatriation period of the students, the learning process of the messageren was partially continued, namely through the online learning model (online) as much as $59.5 \%$; while the rest of the students studied independently or under the guidance of their parents at home as much as $40.5 \%$. This data shows that there are approximately $60 \%$ of pesantren institutions that are ready or dare to try the online learning model; the rest can be assumed that $40 \%$ of pesantren are still not ready to develop online learning models and are still 
passive in using information technology related to the delivery of distance learning.

From the collected data, there were 161 pesantren with the category of only holding recitation (salafiyah model), less than half were ready with online learning, namely $45 \%$. This data also shows that there are $55 \%$ of salafiyah Islamic boarding schools that are not yet literate in online learning technology; meanwhile, in the category of holding activities not only reciting the Koran or kholafiyah model pesantren (out of 986 pesantren) it shows that $61.7 \%$ are ready or dare to try online learning models or $38 \%$ are not ready with online learning technology.

Pesantren Readiness to Organize Online Learning

\begin{tabular}{clcclc}
\hline Types of Pesantrens & Ready & Not Ready & \multicolumn{2}{c}{ Note } \\
\hline 1. & $\begin{array}{l}\text { Pesantren with } \\
\text { Religious theaching } \\
\text { only (traditional) }\end{array}$ & $45 \%$ & $55 \%$ & From 161 Pesantren \\
2. & $\begin{array}{l}\text { Pesantren with } \\
\text { other education } \\
\text { services (modern) }\end{array}$ & $61,7 \%$ & $38,3 \%$ & $\begin{array}{l}\text { From } \\
\text { Pesantren }\end{array}$ & 986 \\
\hline
\end{tabular}

The table above shows that in modern pesantren that not only teach religious studies, the level of readiness to do online learning reaches $61.7 \%$, while pesantren, which are generally salafiyah, which only teach religious studies, show that only $45 \%$ are ready to try online learning. This picture can be understood that the awareness of learning using information technology has been realized almost close to $50 \%$. However, the awareness that pesantren needs to know online learning is quite interesting and needs attention or guidance.

\section{Student Response to Online Learning}

To find out the responses of students in online learning, this study tries to ask the opinions of students through an online survey. This small survey succeeded in capturing data from 31 children from MTS / SMP and MA / SMA students that were achieved by the researcher. The results can describe their response to learning during the 3 months of learning from this house. Here are some of the questions asked of them: the feeling of liking online learning, the difficulties most faced in online learning

Enjoy online learning. It turned out that online learning was only enjoyed by a small proportion of students, namely 7 of the 31 students the researcher met. The rest of the students expressed dislike (11 students) or doubted (13 students). This shows that there is no conducive atmosphere that has been built so that students fully enjoy online learning during the Covid 19 period. For students who like online learning, they like it because they find online learning challenging, all today's problems require high technology and more focused learning. But unfortunately this feeling is only enjoyed by a small group of students. 


\section{Apakah anda menyenangi model pembelajaran model daring}

31 responses

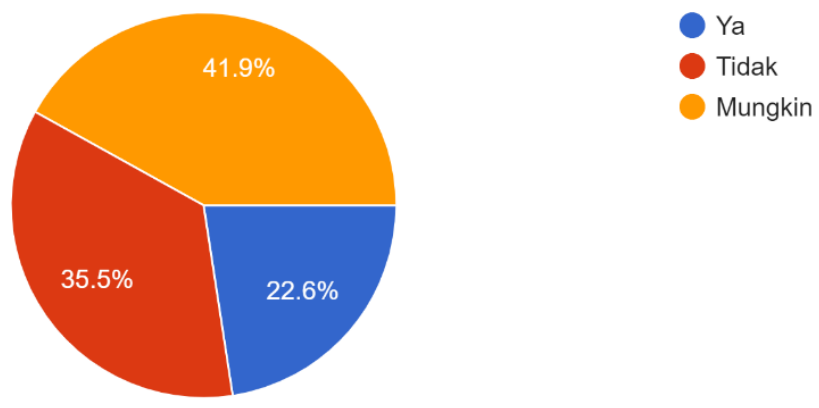

For students who do not like online learning because for them in online learning students have difficulty digesting the subject matter. Of the 31 students, 19 students stated that online learning was still difficult to understand the subject matter. According to them, online learning also cannot take long, there is a proposal for only 30 minutes. One other thing, online learning practices carried out during this pandemic have more educators giving assignments, so students feel very burdened by the large number of assignments.

According to students, the factor that causes unsuccessful online learning is precisely their own, namely students' lack of understanding. Of the 31 students, 19 students answered that their lack of understanding was the cause of not optimal online learning. This figure shows that almost $61.3 \%$ of students are less able to understand learning from online systems. The second factor that causes online learning to be unsuccessful is the limited internet access that the students have. $16.1 \%$ of the collected data stated that limited internet access was the reason for not successful online learning. 
7. Menurut anda, dari faktor-faktor di bawah ini, apa penyebab paling utama pembelajaran daring yang terjadi selama masa pandemo Covid 19 belum bisa optimal?

31 responses

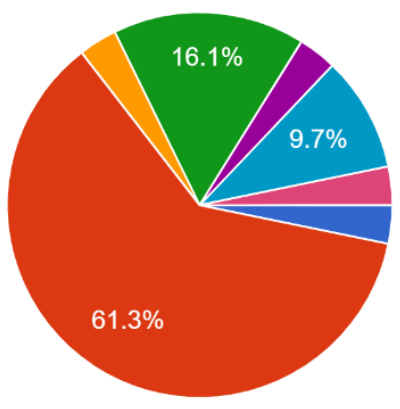

Kemampuan Guru

Ketidakfahaman siswa

Dukungan Orang tua

terbatasnya data/wifi untuk akses internet

Tidak Memiliki HP/Laptop

Kebijakan pesantren

Ketidak kondusifan waktu belajar

Of the online learning models most liked by students from the lecture, dialogue, and others models, the data shows that the lecture model, in which the teacher provides direct subjects to children. Technics can be by zooming, google meeting or their teacher video of the subject that is delivered. After that the online discussion method took second place. One thing that is also interesting is the demonstration of student creations such as making creations based on digital technology such as making vlogs, activity reports based on digital technology.

\section{Model pembelajaran daring (online) yang paling anda sukai?}

31 responses

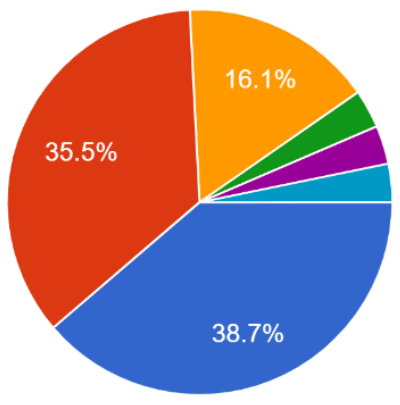

Ceramah guru

Diskusi online

Unjuk kreasi siswa, seperti membuat vlog, reportase kegiatan

di classroom dan diberi tugas tapi dikit aja plus dikasih pemahaman

- Pemberian materi yang berjadwal, pemberian tugas yang sewajarnya,Pe...

Mengobrol/Berbincang" seputar pelajaran

The hope is that after the COVID-19 pandemic, even though online learning faces a number of difficulties, more than half of students want that online learning continues. Some hope to continue with various notes such as improvements in learning methods. But there are also a number of students who want learning from post-Covid 19 to be stopped and return to regular learning. According to them, regular (regular) learning is better able to explain subject matter. 
9. Harapan anda ke depan terkait penerapan pembelajaran model daring (online) setelah pandemi Covid 19 sudah selesai

31 responses

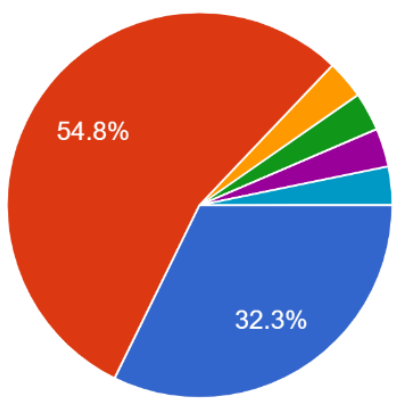

Dihentikan sama sekali

Diteruskan, dengan perubahanperubahan tertentu

Melihat kondisi dan situasi

Menurut saya, Online Class lebih baik diteruskan dengan beberapa syarat $d$...

Jangan banyak tugas, paham tidak pusing iya

Lebih baik dengan cara tatap muka karena itu lebih efektif dibanding online

From the various responses of students to online learning at pesantren in the aspect of the ability to enjoy online learning, the main problems felt by students, online learning that are of interest, and the development of online learning in the future can be described in the following matrix:

\section{Response of Santri An Nahdah to the Implementation Learning Online}

\begin{tabular}{|c|c|c|c|c|c|}
\hline & Aspect & Main Opinion & Second & Other Opinion & Note \\
\hline 1 . & $\begin{array}{l}\text { Enjoy on Learning } \\
\text { Online }\end{array}$ & $\begin{array}{l}\text { doubt } \\
(13)\end{array}$ & $\begin{array}{l}\text { Not like } \\
\text { (11) }\end{array}$ & $\begin{array}{l}\text { enjoy } \\
\text { (7) }\end{array}$ & \\
\hline 2. & $\begin{array}{l}\text { The main problem of } \\
\text { learning online }\end{array}$ & $\begin{array}{l}\text { Not } \\
\text { understandble } \\
(19)\end{array}$ & $\begin{array}{l}\text { Limited access } \\
\text { (5) }\end{array}$ & $\begin{array}{l}\text { Policy of } \\
\text { Pesantren } \\
\text { (3) }\end{array}$ & \\
\hline 3. & $\begin{array}{l}\text { Online learning is in } \\
\text { high demand }\end{array}$ & $\begin{array}{l}\text { Speech } \\
(12)\end{array}$ & $\begin{array}{l}\text { Discussion } \\
(10)\end{array}$ & $\begin{array}{l}\text { Creation show } \\
\text { (5) }\end{array}$ & $\begin{array}{l}\text { From } \\
31 \text { santri }\end{array}$ \\
\hline & $\begin{array}{l}\text { Expectations for the } \\
\text { development of } \\
\text { online learning in the } \\
\text { future }\end{array}$ & $\begin{array}{l}\text { Continued with } \\
\text { modification } \\
\text { (18) }\end{array}$ & $\begin{array}{l}\text { Stop } \\
(10)\end{array}$ & $\begin{array}{l}\text { Look at the } \\
\text { conditions, do not } \\
\text { have many tasks, } \\
\text { continue with } \\
\text { conditions, } \\
\text { preferably face to } \\
\text { face (each } 1 \text { ) }\end{array}$ & \\
\hline
\end{tabular}

\section{Pesantren Problems in Developing Online Learning}

The main problems of pesantren in traditionalizing online learning can be mentioned, first is the problem of culture. In general, until now the pesantren still do not allow students to 
hold the gaget during their nyantri. This is based on the consideration that failure, let alone cellphones interfere with the activities of students who are currently studying at the pesantren. However, there are also a small number of pesantren that have begun to allow students to hold cellphones. However, the mobile phone here is only understood as a secondary communication tool which is not the main method of learning or the Koran. For example, in one of the salafiyah pesantren in Serang, this pesantren does not prohibit students from holding cellphones as long as it facilitates the fulfillment of basic needs of the pesantren such as procurement of supporting materials such as rice, side dishes and so on.

There are also Islamic boarding schools that are trying to deal with current advances in information technology by making mastery of this communication media one of the main subjects of the pesantren. Santri are required to have laptops and cellphones. The Istana Mulia Islamic Boarding School in Serang, for example, here the use of cellphones is even one of the competencies built on students. Santri are taught to be fully aware that in addition to causing madhorot in certain things, gaget is also taught if they are good at behaving, it will become a technology that is needed for students in the future (Murtadlo 2020)

In the case of Pesantren An Nahdah Pondok Petir Depok, until this research was conducted, the board of the boarding school still held the view that students were not allowed to bring cellphones into the cottage. However, for example, if the child brings a laptop to the boarding school, he is welcome on condition that it be registered with the board of the boarding school and the goods are not used because the task is entrusted to the board of the boarding school. The policy was taken because learning in the cottage still relies on face-to-face meetings with the students both in class and outside the classroom.

The second problem is about the problem of infrastructure. The most important need for infrastructure is the availability of data / wifi. The pesantren has indeed provided wifi that can be accessed by both teachers and students. However, the amount of quota provided is still very limited. To launch the content of our learning by the teacher is not much, because the institution with existing funds can do much to do online learning. Problems occur for students, because students also have to buy data to enjoy learning. If there are a large number of students, then just multiply how much data is needed for the implementation of online learning.

The third problem is the problem of the ability of educators to practice online learning. Educators are a key factor in the implementation of online learning. Of the 14 educators in the An Nahdah pesantren, there is a description of their readiness to develop online learning. First, the problem of online learning experiences, most teachers have used technology in learning before the pandemic period. There are two teachers who have not admitted that they have never developed online learning. This shows that most of the educators in this pesantren environment already know online technology, even though it is still simple.

When the Covid 19 pandemic season, it seemed that there were more educators just by giving assignments to students. Half of the 14 teachers admit that. This is also what many students complain about that online learning is more or identical to giving assignments to students. The factor that inhibits online learning is not optimal is the absence of online-based learning guidelines or curriculum. This causes educators to improvise as much as possible with the technology they have. 


\section{Apa hambatan yang paling anda rasakan dalam penerapan pembelajaran daring (Jawaban boleh lebih dari satu) \\ 14 responses}

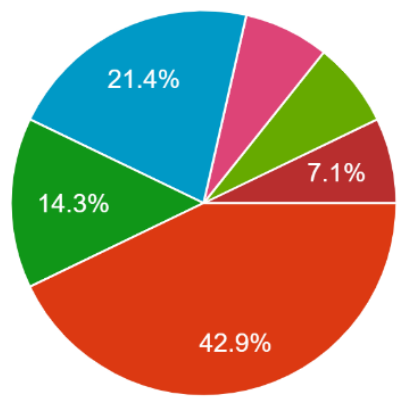
Belum mengenal penggunaan aplikasi daring
Belum mengenal model-model pembe..
Masing bingung memanfaatkan daring...
terbatasnya fasilitas yang disediakan...
kurangnya motivasi/dorongan orang tua
keterbatasan kemampuan siswa men..
Keterbatasan waktu
Pengetahuan penggunaan aplikasi da..
Keterbatasan komunikasi online deng...

What teachers enjoy learning learning models. Half of the teachers who answered enjoyed. According to them, online learning is flexible in terms of time, does not have to go to school, it can be easily implemented from home. Some teachers have not been able to enjoy online learning and some are hesitant to answer. However, if we return to the subject of education, it is the students, of course what is the use of the teacher enjoying it, if the students cannot digest the lesson.

From the assignment side, most of the teachers still assign written reports / assignments. Some are asked to make reports in the form of digital explanations. It also seems to be overwhelming students with the various tasks of all teachers. Teachers tend to think that students at home need to be busy. But at the same time, the students complained that they had a lot of homework to do. In this context, it seems that teachers need to be directed to the assignment report model which is sufficiently reported through non-writing views such as making application creations, shooting that make use of digital technology.

5. Pembelajaran daring seperti apa yang anda gunakan setelah pondok mengambil kebijakan memulangkan santri akibat Covid 19 (Jawaban boleh lebih dari satu)

14 responses

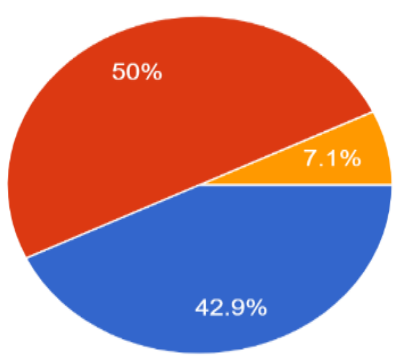

Pembelajaran daring (online)

Penugasan lewat alat media sosial (WA message, dII)

Google classroom, zoom meeting, Hasil diupload ke Ig, fb,dll 
If Covid 19 had ended, 6 out of 14 teachers said they hoped that learning would be returned to normal manually. Teachers teach and interact in class. For other teachers, online learning becomes a valuable experience that subject matter under certain conditions can be carried out online. Online learning is one method to keep student teacher interactions going.

The response of the Ustadz Pesantren An Nahdah to the Application of Online Learning

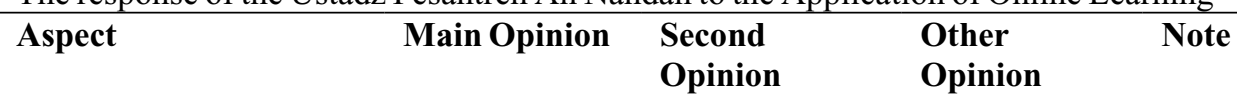

\begin{tabular}{|c|c|c|c|c|c|}
\hline 1. & $\begin{array}{l}\text { Experiment in the } \\
\text { using learning } \\
\text { online }\end{array}$ & $\begin{array}{l}\text { Have } \\
\text { experiment } \\
(12)\end{array}$ & $\begin{array}{l}\text { Haven't } \\
\text { experiment } \\
(2)\end{array}$ & & \\
\hline 2. & $\begin{array}{l}\text { Problem in the } \\
\text { Learning Online }\end{array}$ & $\begin{array}{l}\text { Less of } \\
\text { konledge on } \\
\text { Learning } \\
\text { Online (6) }\end{array}$ & $\begin{array}{l}\text { Incapability on } \\
\text { students } \\
(3)\end{array}$ & $\begin{array}{l}\text { Limited } \\
\text { fasilitation, } \\
\text { limited access } \\
\text { (2) }\end{array}$ & $\begin{array}{l}\text { From } 14 \\
\text { ustadz }\end{array}$ \\
\hline 3. & $\begin{array}{l}\text { Practice learning } \\
\text { online in the } \\
\text { Pandemic era }\end{array}$ & $\begin{array}{l}\text { Give } \\
\text { assignment } \\
\text { (7) }\end{array}$ & $\begin{array}{l}\text { Doing learning } \\
\text { online } \\
\text { (6) }\end{array}$ & $\begin{array}{l}\text { Discussion } \\
\text { (1) }\end{array}$ & \\
\hline
\end{tabular}

The fifth problem, the reason for not optimizing online learning according to educators is that there is no online learning model that is owned by the teacher. As a result, each teacher only improvises with online technology without being guided by clear targets. Moreover, the facts in the field, students also have difficulty digesting course material online. In the future, the government should be able to reproduce this online learning-based curriculum or guide.

The sixth problem is the problem of the ability of students to accept students in online learning. As previously explained, students and Nahdah could not enjoy online learning. Online learning can only be enjoyed by a few students. The reason for their online learning in material is not easy to understand

\section{Online-Based Yellow Book Learning}

Learning the yellow book during the Covid 19 pandemic at the An Nahdah Islamic boarding school also had to be done online. The ustadz reads books recorded or streaming which the students follow at home. This activity is technically easy on the part of the instructor because the cleric lives the recording at any time and then broadcasts it when it's time or the ustadz can read the book streaming from the ustadz's house at the appointed time. In terms of time and place, reading books online is indeed very flexible.

However, from the teacher ustadz's admission, online yellow book learning has several advantages and disadvantages. The advantage is that online book recitation can reach more students, from time to time it can be done at any time as long as the time is set. Meanwhile, from the aspect of weakness, the congregation is less controlled. students whose commitment to the Koran cannot be controlled. Online, they attend the recitation, but in reality the santri may not participate or may even be left asleep. (Interview with Abdullah Mas'ud) 
This online book learning model has recently become an alternative to recitation, especially during the pandemic. However, long before the pandemic, several young NU kyai, such as Kyai Ulil Abshar Abdala, had started with the tradition of online recitation through the recitation of the Ihya Ulumuddin Book. This activity is indeed a breakthrough effort to study books that can be followed by middle class groups in various parts of the world. Santri or students do not need to enter and live in the cottage, but they can participate from anywhere.

Our online learning for Islamic boarding schools an Nahdah is indeed a new method and needs to be tried. Even so, this method for learning young santri or children from the secondary education level is less effective when compared to direct learning. However, the online book learning method is an alternative book recitation that can be given to the public, such as parents of students and also the general public who do have a hobby of participating in online recitation regularly.

\section{Discussion}

In accordance with the original purpose, this paper wants to read the problems in online learning practices in pesantren. From the results of the study of the Islamic boarding school and Nahdah Pondok Petir Depok, it was found that the general response of the students in online learning was not encouraging. In practice, online learning cannot be developed into effective learning. The problems faced in online learning in Islamic boarding schools include: the problem of pesantren culture that has not provided much access to the use of gaget in the boarding school environment, limited data held by students, the readiness of teachers to provide online learning, the absence of online learning manuals, and student aspects or students who are less able to enjoy online learning.

However, from the various problems that exist, there is hope that online learning will be developed in Islamic boarding schools, such as some students who think that online learning needs to be developed even with certain modifications. This view is not the majority view, but at least it provides a gap in hope that some pesantren communities can accept the online learning model. From the teacher's point of view, most teachers actually already know online learning even though it is still limited or at least they admit that the problem of their skills in online learning needs to be improved. From this sentence, the teachers realized that they needed to improve their abilities in using online media in learning.

Responding to this fact, there are several things that Islamic boarding schools need to do in order to make online learning more effective at pesantren. First, the need for new policies related to the use of communication technology in Islamic boarding schools. If all this time it is still strictly prohibited, in the future certain access is needed so that students can use communication media in developing learning. Second, the online learning portion needs to be familiarized with the pesantren environment. Online learning is one of the mandatory methods that Islamic boarding schools need to continue to explore. Third, teachers' skills in online learning need to be improved, given that the success or failure of online learning is very much dependent on the teacher's ability. Fourth, students begin to be accustomed to online learning, bearing in mind the positive use of online media needs to be discussed so that gaget is not understood as merely an entertainment medium or time killing machine for students. This is important so that students can positively understand the presence of digital technology in the daily lives of students later.

The choice to develop online learning in pesantren is absolutely necessary so that pesantren are not left far behind in utilizing technological advances in improving the quality of learning. The implication if online learning does not continue to be developed is that the world of pesantren will be left behind in responding to world developments. Communities outside the 
pesantren, either naturally or forced, have developed and adapted to online media in such a way. The development of the world of technology demands the development of digital literacy for students at the same time.

In addition, the social function of pesantren in the online media climate needs to continue to be present in its new condition. By developing online learning, pesantren are getting used to being present in the world of social media. The online study of the yellow book needs to be continuously pursued to serve the needs of the new social group segment that has just arrived, namely the generation who is familiar with the internet and wants yellow book students to be done online.

\section{Conclusion}

From this study, the author underlines the problem of not working online learning at the An Nahdah Islamic boarding school is due to the assumption that gaget provides more madhorot than benefits for the development of education in pesantren. This is the main source of the problem of pesantren's failure to face learning during a pandemic or the development of postpandemic online learning later. As a result of the persistence of the pesantren's view of the use of gaget, there are various consequences including: there is no progressive thought on the use of gaget in learning in pesantren, teachers are still limited in their insight in improvising online learning, students respond to gaget as an escape from the constraints of the pesantren in responding to the presence of gaget and resulting in The students made gaget as a media with a negative connotation of entertainment and not an item that had the potential to support creativity and productivity.

The conclusion above tends to be different from the general view of the pesantren which still maintains the view that gaget presents more madhorot in pesantren. The difference in this conclusion is because the reviewer focuses more on the implications, both directly and indirectly, on policies based on the view that gaget in the pesantren environment is still insane. The direct implication of this hesitant policy on the use of online media is that pesantren institutions are not optimistic in using online media, the attitude of teachers who are still halfhearted in developing online media in learning, and students who do not enjoy online learning. The indirect implication is that when students are returned to their parents' house, gaget is just entertainment and does not have a positive meaning to increase their creativity.

The author realizes that this conclusion has limitations. These limitations include the technical side of drawing conclusions such as a study that departed from only one case, namely the An Nahdah Islamic boarding school in Depok, West Java. From the online survey that the author conducted, only reached a certain number of responses. It can only read part of the trend (trend). Another limitation of research subjects who tend to be optimistic in seeing problems, so that researchers tend to think about the need for pesantren to start to open up in utilizing information technology and not to be allergic to communication media. However, behind these limitations, the authors hope that pesantren can be more present in the actual development of the latest information technology. May be useful.

\section{References}

[1] ADDIN Mendeley Bibliography CSL_BIBLIOGRAPHY Abidin, Zainal, Rumansyah, and Kurniawan Arizona. 2020. "Pembelajaran Online Berbasis Proyek Salah Satu Solusi Kegiatan Belajar Mengajar Di Tengah Pandemi Covid-19.” Jurnal Ilmiah Profesi pendidikan. 
[2] Arifin, Haris Nursyah. 2020. "Respon Siswa Terhadap Pembelajaran Dalam Jaringan Masa Pandemi Covid-19 Di Madrasah Aliyah Al Amin Tabanan." Jurnal Ilmu Pendidikan dan Ekonomi 5(9). https://journal.staidenpasar.ac.id/index.php/wb/article/view/47/40.

[3] Discenza, Richard, Caroline Howard, and Karen D. Schenk. 2002. The Design and Management of Effective Distance Learning Programs.

[4] Khasanah, Dian Ratu Ayu Uswatun, Hascaryo Pramudibyanto, and Barokah Widuroyekti. 2020. "Pendidikan Dalam Masa Pandemi Covid-19." Jurnal Sinestesia.

[5] Khusniyah, Nurul Lailatul, and Lukman Hakim. 2019. "Efektivitas Pembelajaran Berbasis Daring: Sebuah Bukti Pada Pembelajaran Bahasa Inggris.” Jurnal Tatsqif.

[6] Murtadlo, Muhamad. 2020. "Gagasan Pengembangan Pendidikan Pesantren Berbasis Maritim Di Banten.” EDUKASI: Jurnal Penelitian Pendidikan Agama dan Keagamaan.

[7] Oktawirawan, Dwi Hardani. 2020. "Faktor Pemicu Kecemasan Siswa Dalam Melakukan Pembelajaran Daring Di Masa Pandemi Covid-19." Jurnal Ilmiah Universitas Batanghari Jambi.

[8] Padli, Feri, and Rusdi. 2020. "Respon Siswa Dalam Pembelajaran Online Selama Pandemi." Social Landscape Journal 1(3): 1-7. http://103.76.50.195/SLJ/article/view/14508.

[9] Pujiasih, Erna, and S M A Negeri Bantul. 2020. "Membangun Generasi Emas Dengan Variasi Pembelajaran Online Di Masa Pandemi Covid-19 Building a Golden Generation By Applying Various Online Learning in the Pandemic of Covid-19." Jurnal Karya Ilmiah Guru.

[10] Setyorini, In. 2020. "Pandemi COVID-19 Dan Online Learning: Apakah Berpengaruh Terhadap Proses Pembelajaran Pada Kurikulum 13?" Journal of Industrial Engineering \& Management Research (JIEMAR)

[11] Viner, Russell M. et al. 2020. "School Closure and Management Practices during Coronavirus Outbreaks Including COVID-19: A Rapid Systematic Review.” The Lancet Child and Adolescent Health. 